\title{
FROM THE WITCH TO THE FAIRY: EDNA ST. VINCENT MILLAY'S EXPLORATION OF WOMEN IN POETRY
}

\author{
Ana Abril Hernández, Independent Scholar \\ Email: ana.ab.her@gmail.com
}

Received: July 27, 2020

Accepted: December 7, 2020

\begin{abstract}
The first decades of the twentieth century in America witnessed the emergence of one of the most famous feminist writers of that time and whose fame disappeared as rapidly as it came: Edna St. Vincent Millay (1892-1959). Her light and transgressive verse soon placed her as one of the poets that best represented the Roaring Twenties transgressing sexual and social taboos in an America dominated by the figure of the flapper that this writer perfectly embodied. This study delves into Edna St. Vincent Millay's poetry and the representation of women in her works.
\end{abstract}

Keywords: Poetry, Edna St. Vincent Millay, feminist literary criticism, semiotics, subjectivity.

Resumen: Las primeras décadas del siglo veinte en Estados Unidos fueron testigos del surgimiento de una de las escritoras feministas más célebres de la época y cuya fama desapareció tan abrumadoramente como llegó: Edna St. Vincent Millay (1892-1959). Su verso ligero y transgresor pronto la situó como una de las poetas que mejor representaba los "felices años veinte" transgrediendo tabúes sexuales y sociales de una América dominada por la figura de la flapper que esta escritora encarnaba a la perfección. Este estudio profundiza en la poesía de Edna St. Vincent Millay y la representación de la mujer en sus obras.

Palabras clave: Poesía, Edna St. Vincent Millay, crítica literaria feminista, semiótica, subjetividad.

\section{INTRODUCTION}

Edna St. Vincent Millay was born in Maine in 1892 to Cora Lounella Buzzell and Henry Tollman Millay and died in New York in 1950. Millay first lived in Rockland, Maine, and moved to Camden, Maine, after her parents' divorce. Her love for music (she 
could play the piano), languages, art and poetry was her mother's gift for her and her two sisters (Norma and Kathleen). She attended Vassar College for women and obtained a Bachelor Degree in Arts in 1917. After graduating, Millay led a Bohemian life and as she developed even more her career as a poet. In the year 1923 she received the Pulitzer Prize for Poetry for The Ballad of the Harp Weaver, a poem she dedicated to her eversupportive and loving mother, Cora. This American female activist and poet was also seen as the "Girl Poet" (Millay 2002: xv) who represented most faithfully the post-war generation of the so-called 'Jazz Age' or Roaring Twenties. Millay published her first works under the pseudonym of Nancy Boyd, which was also her great-grandmother's maiden name (Goddu 2016: n/p), but her choice of her name bears more with it than it seems. She also chose to be called Nancy Boyd in reference to the "derogatory slang for an effeminate boy, and also forms an anagram of 'Body"' (Keyser 2010: 21) being this only one more of her creative and rebellious marks.

Her poem "Witch-Wife" is contained in her first collection of poems: Renascence and Other Poems, a highly praised publication since its appearance in 1917. This collection was intended to renew the poetic language of the early twentieth century with vivid metaphors providing fresh air to the literary panorama of her time. It was directed (much more so in the case of her second collection) to the young generation of Americans (Dell 2017: n/p) who sought new artistic forms of expression within a language that, as her contemporary Modernists writers agreed, was too full of clichés and repetitive images. The success of this book was soon followed by her second collection: A Few Figs from Thistles: Poems and Sonnets from 1921, an edition which had been published the previous year with less sonnets in it, where "The Singing-Woman" was published. If the first collection paved the road for the readers' appraisal for its light-heartedness and open representation of everyday life, the second collection, while still well-received, met critical rebuke for its outspoken homosexual love affairs (e.g., "First Fig") and unrepentant liberation as a woman (e.g., "The Penitent"). ${ }^{1}$ The latter book brought about the extended acceptance of the figure of Edna St. Vincent Millay as the quintessential New Woman.

The overall tone of the collections of poems that contain "Witch-Wife" and "The Singing-Woman from the Wood's Edge" (hereafter shortened as: "The Singing-Woman") overtly challenges the old values and mentality of the Victorian times they were slowly leaving behind. The rebellious attitude in the pieces of poetry published in those books proves Millay's serious concern about the quest for the subjectivity of the self in an attempt to find a place of belonging among her peers, which is the notion that Millay discusses in "The Singing-Woman." As for "Witch-Wife," the persona assumes a male voice and laments his lover's wicked ways toward love, which offers an intriguing vision of independent women from the eyes of a male lover. Alternatively, "Witch-Wife" could also be read as a female speaker who refers to another woman. However, the two last lines hint at a masculine speaker and they read: "But she was not made for any man, / And she will never be all mine" (11. 11-12).

1 For a deeper analysis of the representation of women in Millay's poem "The Penitent" and the distinction between Millay's private and public sides of herself, see Ana Abril Hernández's article: "Revisiting Edna St. Vincent Millay, the Forgotten Authoress who Marked a Generation" (2019) (full reference at the end of this article). 
Her sonnet "The Singing-Woman" also bears the musicality of the ancient odes not only in the rhyming pattern and the fantastic elements in it, but also in the very fact that its narrator is singing. The ancient odes and Classical poems were an influential literary basis for this writer, and she was passionate about the ancient world since her early childhood. In a way this poem represents her own life (it is semi-auto-biographical), ${ }^{2}$ she leaves part of herself in these lines. The carefree narrative style of this woman in the wood's edge reminds us of Sharon Olds' poems about the body, both male and female (mainly her Odes from 2016). Sexuality is most starkly present in Olds' poems in a certainly explicit fashion in which the female body is praised and presented taboo-lees. In her "Ode to Menstrual Blood," Sharon Olds celebrates this monthly moment in the life of every woman and of this blood as "hardy / elixir, transparent manna" (11. 21-22). Similarly, Anne Sexton's poetry celebrates femininity in a poetic vindication of the female body and social roles assigned in poems like: "In Celebration of My Uterus" with lines like: "They said you were immeasurably empty / but you are not" (11. 5-6) and some poems which sing the maternal bond with the mother: "A woman is her mother. / That's the main thing" (11. 9-10) in her poem: "Housewife."

The present article examines Edna St. Vincent Millay's poetry in the light of poststructural feminism, in particular the semiotician Julia Kristeva's study of poetic language as the semiotic mechanism of communication of the subject in process. In particular, this research examines the way women are presented and treated in her poetry, this study focuses on two poems by this American author: "Witch-Wife" and "The Singing-Woman from the Wood's Edge" from a feminist perspective. The following sections draw on the notions of poetic language and subject in process as understood by Kristeva with a view to provide a closer look at Edna St. Vincent Millay’s poetry.

\section{POETIC LANGUAGE AND THE SUBVERSION OF GENDER IDENTITY}

Language (and art in general) is broken down to its most basic components by the avantgardes for the purpose of bringing new poetic momentum to its creative and communicative potential and, thus, to the poetic expression of the self. The speaking subject that turns to poetry, as Millay does, explores her own subjectivity by means of the language she uses so that the insight into the individual is manifested in poetry in the lines of a poem. Millay was exceedingly subtle in permeating her pieces of poetry with vivid images of womanhood and empowered women, as her poems "Witch-Wife" and "The Singing-Woman" shall prove. The subject in process depicted in these poems is eternalized in the very language used to describe them.

Millay's stylized language merges the old poetic forms-such as the sonnet-with uniquely modern views on society and women-as can be seen in her overt expressions

2 It is not uncommon to find auto-biographical references in her literature. For instance, in her poem "The Ballad of the Harp Weaver" some critics have seen traces of her own poor childhood and of her mother's in the male narrator of this ballad disguising a most grim theme, a matricide as Nancy Milford claims in her introduction to Selected Poetry (2002: xvi). 
about female emancipation and homosexual love. ${ }^{3}$ Her poetic style escapes the linguistic and thematic restrictions of her time as she aims at finding new ways of expression with the written word and imagination as its most powerful allies. Poetic language is indeed, an unconventional mechanism to disrupt the order received and, with it, to deconstruct and reconstruct her own identity. For this reason poetry reveals itself in Millay as a battle horse against patriarchal society and the mores of the America of the twentieth century. In her essay "The Subject in Process" Julia Kristeva refers to the poetic language as a process towards self-discovery by breaking down the traditional, natural language which is opposed to the scientific language (Kristeva 2002: 27). Millay's poetic style, although seemingly simple and childish (see the poem "The Singing-Woman") bespeaks a veiled meaning, a will to subvert the norms in the semiotic current of inferences that flows beneath the surface of the lines. As the executor of the Edna St. Vincent Millay Literary Estate Holly Peppe asserts: "like Donne, Millay creates irony and paradox with ingenuity and boldly uses conceits, archaic language, inversions and complex syntax, adding only twentieth-century colloquial diction as her poetic signature" (Millay 1998: xxv).

The language in Millay's poetry revitalizes this genre thanks to the unusual combination of aesthetics and ethics (i.e., form and subject matter). This renewal of a literary genre adds went hand in hand with her rebellious attitude adding to the legend she forged for herself as the prototype of the American flapper, the New Woman. Her poetic style draws largely on intimate moments described in her poems with emotive references to emotional states which are universal, a property that makes her pieces of literature immortal and relatable. Her lyric style is far from that of her peer poets of her time: "when Millay was expressing attitudes and feelings in (for the most part) conventional poetic forms, other poets-led by Ezra Pound and T.S. Eliot-were expounding a new theory of poetry that rejected the expression of emotion" (Millay 1998: xix). In many of her poems she examines the ways in which female subjectivity can be expressed in words; yet that which is not said outweighs the denotative meaning in her lines. "The Penitent" is one of her most rebellious poems and in it, Millay admits that she has been "a wicked girl" (1. 22) only to state: "'But if I can't be sorry, why, / I might as well be glad!" (11. 23-24). Similarly, the woman in "Witch-Wife" shows an eerie mixture of romanticism and pragmatism since she: "learned her hands in a fairy-tale, / And her mouth on a valentine" (1. 11. 3-4), which separates her from the image of the 'angel in the house.'

In "Witch-Wife" the narrator makes use of beautiful and baroque metaphors to describe the unbearable and unattainable beauty of this woman-witch. The four quatrains that make it up are enthralling and obscure. The rhythm is used to enhance the poetic lyrism of this piece, which increases the evocative power of this poem. In many of her works, Millay has her narrators sing the deeds told in them in the manner of the Greek poets like Homer and the troubadours in the Middle Ages (e.g., "Dirge," "She is Overheard Singing" or "The Singing-Woman," among others; even in her drama piece Aria da Capo).

3 The first female amorous affaire she had was during her stay at Vassar College, an infatuation for the actress Wynne Matthison to whom the poet addressed in one of her letters in a most intimate and plain manner: "When you tell me to come, I will come, by the next train, just as I am. This is not meekness, be assured; I do not come naturally by meekness; know that it is a proud surrender to You" (Millay 1952: 71). 
In her study "Desire in Language" contained in: The Portable Kristeva this BulgarianFrench semiotician examines the musical and rhythmic properties of poetry which articulate the writer's understanding of the chora ${ }^{4}$ as the semiotic receptacle of women's creative power (2002: 101):

$[\mathrm{T}]$ here is within poetic language (and therefore, although in a less pronounced manner, within any language) a heterogeneousness to meaning and signification (...) detected genetically in the first echolalias of infants as rhythms and intonations anterior to the first phonemes, morphemes, lexemes and sentences; this heterogeneousness to signification operates through, despite, and in excess of it and produces in poetic language 'musical' but also nonsense effects that destroy not only accepted beliefs and significations, but, in radical experiments, syntax itself, that guarantee of thetic consciousness (of the signified object and ego).

"Witch-Wife" operates in the space between the realm of fantasy ("She learned her hands in a fairy-tale" 1.3 ) and the resentment of a lover who knows that he will never win the woman's love. This bitterness disrupts the melodic pattern of the poem, which transports us, albeit temporarily, to the fairyland of "The Singing-Woman." This is the major achievement of the poetic language in this poem: to subvert the male-dominated stereotype of the devoted wife by replacing it with a witch-wife. This is the 'heterogeneousness' Kristeva refers to: the increasing number of possible interpretations of a poem, its semiotic polyphony. Millay's is not simply a woman but a wife, showing a rebellious attitude towards the institution of marriage as regards the traditionally-held passive role of women in it. In fact, her insurrected behavior as regards this institution was such that her marriage with the Dutch importer Eugen Jan Boissevain was an open one in which each of the two members was allowed to indulge into occasional love affairs. As one of her biographers, Miriam Gurko, has claimed in her book: Restless Spirit: The Life of Edna St. Vincent Millay: "Edna used to say, 'Eugen and I live like two bachelors.' She had the same complete freedom that she had before marriage and without which she could not function. She had never, as she put it, 'settled down"' (1962: 167). This aspect of her personality matches notably the stereotype of the witch-wife she egotistically depicts in her homonymous poem.

In this poem Millay appeals to the senses in an attempt to boost the sensuous charge of her wild wife. She starts from a description of her external aspect: "She is neither pink nor pale" (1. 1) and in the same stanza she describes her hands and her mouth (11. 3, 4). The second stanza stops on her hair and her voice $(11.4,6)$ and finally, the last one only mourns about the love that the speaker will never receive from her. Again, the poetic language runs underneath the visible meaning in the poem: from an initial seemingly external description it is soon made clear that this is not as superficial as it seems at first sight. The color of her skin, her hands, her mouth, her hair and her voice reveal a merciless woman from the point of view of the narrator. He sees all her attributes from within, through the lens of a rejected lover, thus turning the apparently objective, external features of this woman into her internal self-sufficiency and his internal frustration. We have no information about whether she is aware of her lover's feelings or not because although the narrator allows for certain

4 In her study: Bodies that Matter (1993) Judith Butler makes a revision of Kristeva's understanding of the semiotic chora by suggesting the disconnection between the maternal body and the prediscursive chora. Nonetheless, it is worth noting that for Butler the maternal body does not hold a one-to-one link with the chora. 
moments of insight into her mind, there is no single clue as for her emotions and feelings. It is the voice of the speaker that dominates the poem, which once again (assuming it takes on a male tone in view of the last lines), presents the woman as an unreachable deity seen from the exterior with little or no chance of knowing her desires.

Indeed this witch-wife directs readers to the image of a femme fatale in the physical description made by the speaker and the impossibility to enter into her psyche. The narrator knows, however, that she "loves [him] all that she can" (1. 9), which shows that, at least, he has a slight grasp of her thoughts about him. The outer and seemingly objective description presented in the first stanza reads that "she learned her hands in a fairy-tale, / And her mouth on a valentine" (11. 3-4) which implies that there is indeed a semiotic current of meaning underneath the written lines in this poem: that which the narrator knows and does not say. Otherwise, he would ignore the reason why she acts in public the way she does (symbolized in the affected manner of moving her hands) or why she can use language in such a bewitching fashion (symbolized in the comparison between her mouth and a valentine). The narrator does, indeed, know more about her than it seems, an information that is presented in the guise of an objective, external observer of a sensuous woman.

If language, as the Modernist writers noticed, was not a reliable mechanism to reach the essence of the world, it would not be very far-fetched to wonder about the virtual impossibility to ever attain any knowledge of the human subject. This issue is best tackled by considering that, firstly, language alone is not a valid means to know the reality of the phenomenological world-since our senses do not provide complete or solid information about the world-and, secondly, that the world may actually not be a homogeneous and fixed matter outside our cognitive reach. It follows that the world is as unstable as the words we use to refer to it which, in turn, implies that the identity of the individuals we describe with the linguistic sign are as temporary as the words whereby we describe them. As the Professor of English Literature Ruth Robbins states in her study: Literary Feminism language, in Kristeva's view, is not the definite mechanism to attain a univocal reference to the world since language is as mutable as the world itself (2000: 126):

[Poetic] language stretches our conceptual frameworks and liberates our thinking. It is a language distinct from that ordinary language use for communication, the language of everyday speech, though it is recognizable within the terms of such ordinary communication. But it is also a language that draws attention to itself as language, a language of materiality, rather than the apparent transparency of ordinary speech in which the reader/hearer is encouraged to forget the words and to move straight to the world to which the words are supposed to refer. Poetic language advertises the writer/speaker's efforts to encase concepts or objects in sounds and rhythms. The recipient of such a language is therefore encouraged to notice language in use, rather than moving directly to the 'reality' or the abstraction to which the words are supposed to refer.

Poets are, in this respect, the most representative users of poetic language since they deepen into the networks of meaning-making semioses that take place at the intra-linguistic level avoiding connections between language and the world. Millay's use of an evocative language so colorful and full of ornamental elements in "The Singing-Woman" stands in accordance with the poetic property of language in her depiction of the poem's imaginary world. In this sonnet, a tacit pact of 'willing suspension of disbelief' (as Coleridge would 
put it) calls for the combination of fantasy beings (a leprechaun) and real ones (a friar) (1l. $2,14)$. By carefully intermingling reality with fiction mediated by poetic language, Millay manages to present in a nonchalant tone her father's "prayer for [her] death and a groan for [her] birth" (1.21). The crude reality is presented in this poem in a most charming way thanks to the poetic images and recurrent childish elements of fiction contained in it. Despite the sorrow that fills her personal life - her father's indifference towards her, and her parents' struggle to gain her affection (1.34) - this woman is "singing" as we are informed in the title of the poem: poetry sooths her pain, relieving her from the troubles in the 'real' world.

The language that this American writer exhibits in this sonnet is poetic in the sense that it directs readers towards a totally different realm outside the physical world. In this world is where her narrator can exercise freely her sense of 'I' or, at least, pursue it. This woman is not as determined in her quest for her inner voice as the witch-wife from the previous poem. Now, this narrator is explicitly in-between two states, two worlds: she is neither inside the forest nor outside it but in the "wood's edge." It is worth noting at this point the relationship between the witch-woman and that which is considered as evil, dangerous, attested by the title of the first poem and the reference to the girl in the second one as the "fiend's god-daughter" (1. 4). Both pieces show a negative view of women, at least at first sight, but since in Millay appearances are very deceitful, a careful reading of these poems serves to illustrate her understanding of female subjectivity and its poetic manifestation.

The poetic language becomes now a most useful resource to investigate the sense of belonging of a poet. Consequently, in contrast to the organic life of the modern individual identified by Kristeva, language imposes its strict and closed structures on the same subjects who use it in order to discuss their subjectivities. For instance, the poetic 'I' of the American writer Walt Whitman did not aim at representing his personal, unique voice; this poet aimed at voicing the thoughts and ideas of an entire nation. In one of the letters she sent to her sister-in-law Susan Dickinson, the Romantic poet Emily Dickinson claimed that "We meet / no Stranger / but Ourself" which turns all the more relevant in the light of Millay's questioning about who she is.

"The Singing-Woman" has the semblance of a poetic quest for the narrator's identity, but in fact, the rhetoric questions that pervade the poem and the immediate answers provided by Millay suggest that she already knows the answer. For example, the first line (which sets the self-reflective tone of the poem) reads: "What should I be but a prophet and a liar" (1. 1). The narrator admits a divide between her identity and the world that surrounds her, in which she only feels partly at home. The persona in this poem feels at home only when she is in the realm of the fantastic (understood here as the imaginary beings such as the mermaid, the leprechaun, the pixie mother, etc.), not when she speaks of her parents. The first step towards the poetic creation of is "the realization of the separation of self and world" (Robbins 2000: 114), which implies that in order to find a way of self-expression a poet (and any writer as well) has to distance himself or herself from the world first as a sign of his or her awareness raising. Poets are in this sense probably the most sensitive creators of alternative worlds since they command readers to abandon their daily lives in order to plunge into a world governed by the mesmerizing musicality of poetry and its stimulating language. It is precisely this rhythmic language what best accounts for the organic flow of 
meaning that characterizes the subject in process. This subject lives in a perpetual process of creation and re-creation as the next section discusses.

\section{A BOUNDLESS SUBJECT IN PROCESS: "SHE WAS NOT MADE FOR ANY MAN"}

The poetic personas in poems are the literary devices that mediate the world raised by the author and the readers' and writer's own. For this reason, readers must be aware of the dynamic quality both of the language and of the subjectivity of this persona. Kristeva offers a psycho-semiotic approach to the notion of the "subject in process or in trial" in her study: Revolution in Poetic Language published originally in 1974. In it, she states that individuals can no longer be understood as unitary beings, immutable and stable entities for whom changes barely occur. Instead, she argues, we should place them in the middle of the stream of stimuli and experiences that shape their (our) sense of 'I' thus enriching the modern subject and breaking the former alienation that separated the Cartesian cogito from the phenomenological world. As a result, we come across subjects-in-process or on trial (Kristeva 1984: 81) for whom negotiation with the external individuals help this speaking subject in the everlasting process of construction and reshaping of his or her subjectivity. Kristeva makes the remark on her theory of the subject in process by calling it a "speaking subject" (Kristeva 2002: 26) since "if language is a dynamic process then the subject is a dynamic process" (Kristeva 2002: xviii).

As a result, the subject needs to be perceived as an open-ended process of becoming, never as a fulfilled and complete unity. Here is where the notion of identity heterogeneity enters into contact with the literary multiplicity of voices in a poem or in a novel. This is the extent to which Millay's sense of 'I' is projected onto her poetry: inasmuch as she explores women's private spheres of sexuality, passion, love and the role they have been assigned in their societies. As Robbins has claimed the subject is in close relationship with the text that it produces and which embodies its being in process so that the act of writing and the writing subject become indissolubly joined: "[any] text (and any subject) is polyvalent, polylogical, plural, unfixed. (...) The subject is always in process in that $\mathrm{s} /$ he is not fixed, but always developing. But also, the subject is always in process because $\mathrm{s} / \mathrm{he}$ is always on trial, being tested against the various contexts in which s/he has his/her being" (2000: 127). It follows that "for the subject in process, woman represents that heterogeneous being who doubles up unity, who separates it, and who it is indispensable to control, struggling with her without sublimating her into a virgin-mother" (Kristeva 2002: 149-150). Therefore, the woman reveals herself as the subject given that she has had to overcome socially-imposed roles, has maintained a historical struggle for her independence (both as a citizen and a woman; i.e., in the public and the private spheres) and has seen her identity reduced to the minimum in some cases with the imposition of a name that was not her own.

The former case (the identity through a name, a linguistic-symbolist manifestation of a woman's sense of I) is made the object of poetic interest in the poem: "The Prisoner" from Millay's second collection of poems. Millay, who liked to be called 'Vincent' (Atkins 1964: 2) complains in this poem about the meaningless of words, of a name: "What's in a name?" (1. 3) she questions. This writer knew that for people words are only their way 
of communicating, but her poetic side told her that there is more than meets the eye in a simple word if you choose it carefully and place it in the right position in a poem. Thus she laments the social norms she received which she does in a perfect match between her role as a woman and the language that so restrict her in her roles: "I guess I'll be locked into / As much as I'm locked out of!" (11. 4-5). Indeed, she is 'locked into' a name in the sense that a person's subjectivity can never be summarized in a name (much less if, as many female writers complained, you are forced to abandon your family name and take your husband's in its place). But the second part of her complaint reveals that she also feels locked outside the boundaries of language (however poetic it may be). She uncovers her inner fears and worries in her statement: "as much as I'm locked out of" (1. 5) because she does acknowledge the tight space allocated to women in her time and the many struggles and criticism they had historically had to overcome.

The subject is always in the process of redefining itself in Millay's poetry as "The Witch-Wife" illustrates. This short poem is an ardent declaration of intent, of her will to belong to herself and to no one else. In her biography of Millay: Girl Called Vincent: The Life of Poet Edna St. Vincent Millay Krystyna Goddu refers to this poem as: "a lighthearted declaration that whatever her passions and pleasures, at heart the subject of the poem belongs only to herself" (2016: n/p). Though the topic of the poem is clear (a lament for a woman that the narrator cannot have), the speaking voice is concealed to readers throughout the poem so that they are left to wonder if the narrator is Millay herself (in a sort of lesbian lament for a woman she will never have). This ambiguity in the identity of the speaking subject is maintained until the two last lines: "But she was not made for any man, / And she never will be all mine" (11. 11-12) which show that the narrator is a man. This willing deceitfulness in the gender of her narrator is what turns this poem into an interesting piece of subject analysis from the stance of gender and semiotics. In it Millay uses language conveniently to disrupt gender assumptions about love while simultaneously asserting her (and women's) right to be their own masters with the double repetition of the line: "and she never will be all mine" (11. 2, 12).

From the point of view of a subject that is not fixed, this poem is informative about the woman it refers to as well as about the speaker who describes her. This can be seen from the first line in the enumeration of traits chosen to describe the speaker's object of affection. The narrator focuses on outer elements which, as this study has examined, hint at an interest and knowledge in her private life on the part of the speaker. The 'objectification' of the woman in this poem allows the persona to compare her to a witch who is wicked to her lover because she enforces her right to own herself. The title of the poem indicates that it is a man that is narrating his miserable feelings about her detached manners and, in a most intriguing switching of roles, turns her into the unattainable woman, the temptress in total control of her life and her destiny and him, into her victim.

The woman in "Witch-Wife" is observed and judged and to a certain extent she is also aware of her power over the man, much like the stereotypical vampire woman, the femme fatale and the temptress stereotypes have shown. This can be noticed when the narrator declares: "her ways to my ways resign" (1.10) so that she is presented as a woman who is able to control men by being in complete control of her womanhood, celebrating it and subverting the classical dangers and risks that men identified in the types of women 
aforementioned. A similar attitude is presented in her poem: "Oh, think not I am faithful to a vow!" as the narrator assumes once more a detached attitude regarding her lover to the extent that the narrator even claims: "Faithless am I save to love's self alone" (1. 2). The subject in process is now rejoicing her full independence and the power ensued over her male companions. However, not all of Millay's poems depict a self-sufficient woman, partly evil in advocating her independence from men. As the following lines show, in her sonnet "The Singing-Woman" Millay uses a retrospective literary device to account for the "witchwife' she has become (assuming noticeable similarities between that woman and its author).

It comes as no surprise in the light of this psycho-semiotic approach to the ontology of the modern subject that the narrator in the poem "The Singing-Woman" is not only speaking but singing. Singing represents here the utmost manifestation of the subject's "selfness." This self-reflexivity is accentuated by the fact that she is singing about herself. The first line of the poem initiates the quest: "What should I be but a prophet and a liar" (1. 1) and the process (or trial, quoting Kristeva) ends in the last line of the poem: "What should I be but just what I am?" (1.36). Often, when we verbalize the events and specific moments in our lives we resort to the narrative form (Kristeva 1984: 90). But there are a few aspects of the obscure process of narrative search at stake in this poem. In the first place, it is rather unusual that a response for any question (the first line) is answered with another question (the last line); this assumes a never-ending process of (re)creation of the subject, as the French semiotician indicates in her theory. And in the second place, a fact that may pass unnoticed after the abundant answers to her search of her inner 'I' (i.e., a prophet, a liar, the fiend's god-daughter, a harlot, a nun): what is she in the end? This lack of a final, definite answer for such an existential query points at the direction mentioned before in this study: there is no possibility for a closed-up, immutable definition of what a subject is.

What is most fascinating in this poem is the subtle and poetic manner in which the author navigates the mind of her narrator and places her in a world where she seems at ease only to avoid giving a clear answer to her initial inquiry about her. Yet, the fact that it is the narrative voice herself who is wondering about who she is with no outer voice offering external comments on her, restricts the margin of interpretation of this narrator. Nevertheless, this is not always a drawback. Readers may not have access to what the others think about this lady-fairy from the woods but we know what she thinks and, more importantly, how she describes herself. It could seem that sometimes, in omitting something we are actually covering it up, erasing it or veiling it; but this is just the opposite in this introspective poem. It is in the lack of a final response to her question and to the fact that she defines herself at the very end of the poem as: "just what I am" (1. 36) that readers realize the cognitive process that has worked in Millay's mind across the poem. This has not been an actual quest for inner voice but rather a solid statement of what she sees in herself and what the others see in her. In consideration of this reality we come to understand better why she combines such contradictory pairs as: harlot and nun or prophet and liar.

In Blood Too Bright: Floyd Dell Remembers Edna St. Vincent Millay Floyd Dell would describe Millay as "a rebel, and her poetry has a background of revolutionary idealism" (Dell 2017: n/p). This view of Millay as a rebel is the image that the America of her time had about her as a woman and a poet. The singing-woman in her poem is nothing less than a melting pot of her own view and the opinions of others about her, a negotiated entity that 
she embodies in the fairy of this poem. She was well aware of the image she projected of herself, which had towered her as the brightest New Woman of her era (at the level of other writers such as: Charlotte Perkins Gilman and Kate Chopin) and later on eclipsed her fame as she introduced political propaganda into her poetic repertoire (Dell 2017: n/p). As Suzanne Clark puts it: "Millay also positioned herself firmly on the side of progressive politics, not only in her public life, but in poems like 'Justice Denied in Massachusetts,' on the on the Sacco-Vanzetti case" (1995: 4). The poetic language is the vehicle for the expression of the new conception of the subject as an entity in perpetual questioning of its identity (or, rather 'subjectivity,' as Kristeva called it). In this sense, the narrator and protagonist of the poem does not aim to reach a final conclusion, but to present the conflation of terms that she was socially compelled to align with.

\section{CONCLUSIONS}

This article has analyzed Millay's use of the traditional poetic forms such as the sonnet to introduce her revolutionary ideas about the New Woman while at the same time subverting the classical inherited view of women as muses vindicated now as creators of art, as some critics agree (Fried 1986: 2). This poet aimed at undermining gender roles classically accepted and her rebellious poetics turn to daily moments of our lives (e.g., the trip on a ferry in "Recuerdo") or transform the passive agency of women into active engagement in love and society (e.g., her philosophical thoughts in "The Philosopher" or "The Merry Maid"). Millay permeated objects, people and moments in time with a meaning that calls for a revision of the place of women in the private and the public realms. Kristeva uses this concept to complete her theory of the subject on trial referring to the space which enables an articulation of the organic chain of meaning-making practices which define us and model our subjectivity (Kristeva 1984: 25-26).

The purposefully ambiguous poetic persona in the first poem blurs all gender frontiers, the same gender categorization that marked the female roles that this very poem undermines. By presenting a witch as the center of a poem-and, as discussed before, a witch wife-, Millay draws on inherited gender stereotypes (such as the witch as temptress) and twists them, playing with the readers' expectations (which, for a reader knowledgeable of her sexually open style does not come as such a surprise, nonetheless). The speaking subject is here presented under the appearance of a man, but we know that it is a woman poet that is behind him and, similarly, he speaks about a woman (supposedly his wife) with whom he does not interact. This research has shown how this apparent objectivization of the woman is counteracted in the fine-drawn psychological description of this 'witch' hidden under the cover of a mere physical description. In this poem, the psychological traits of this femme fatale are presented as if they were the more or less objective account of her observable qualities. The combination of these two aspects in "Witch-Wife" reveals the genuine capacities of this American poetry craftswoman.

To conclude, "Witch-Wife" presents some poetic traits that aim at immortalizing the woman it describes. In this sense, the child that once lived in the wood's edge has grown to be a strong-minded woman whose agency transforms her into her most valuable possession, the empowered woman in "Witch-Wife." This is the most accurate instance of a subject 
in process, as Kristeva presented it. A subject, that, just like Millay's heroines and herself, change, learn and adapt to their new circumstances because nothing can stop the movement not even the still picture she draws of her witch. In fact, even in that case do readers, critics and scholars still struggle to find the hidden 'figure in the carpet' proving that these poems from the 1920s still spark our imagination and live as the poetic offspring of the American Calliope: Edna St. Vincent Millay.

\section{REFERENCES}

Abril Hernández, A. 2019. "Revisiting Edna St. Vincent Millay, the Forgotten Authoress who Marked a Generation." Gendered Ways of Transnational Un-Belonging from a Comparative Literature Perspective. Eds. I. Mukherjee \& J. Singh. Newcastle upon Tyne: Cambridge Scholars Publishing. 176-189.

AtKins, E. 1964. Edna St. Vincent Millay and her Times. New York: Russell \& Russell.

Butler, J. 1993. Bodies that Matter: On the Discursive Limits of "Sex." New York: Routledge.

Clark, S. 1995. "Uncanny Millay." Millay at 100: A Critical Reappraisal. Ed. D. F. Freedman. Carbondale/Edwardsville: Southern Illinois University. 3-26.

Dell, J. 2017. Blood Too Bright: Floyd Dell Remembers Edna St. Vincent Millay. New York: Glenmere Press.

FrIED, D. 1986. “Andromeda Unbound: Gender and Genre in Millay's Sonnets.” Twentieth Century Literature 32, 1: 1-22.

Goddu, K. P. 2016. A Girl Called Vincent: The Life of Poet Edna St. Vincent Millay. Chicago: Chicago Review Press Incorporated.

Gurko, M. 1962. Restless Spirit: The Life of Edna St. Vincent Millay. New York: Crowell.

Keyser, C. 2010. Playing Smart: New York Women Writers and Modern Magazine Culture. New Jersey: Rutgers University Press.

Kristeva, J. 1984. Revolution in Poetic Language. Trans. M. Waller. New York: Columbia University Press.

Kristeva, J. 2002. The Portable Kristeva. Updated Edition. Ed. Kelly Oliver. New York: Columbia University Press.

Robbins, R. 2000. Literary Feminisms. Basingstoke: Palgrave.

Millay, E. St. V. 1998. Early Poems. Ed. Holly Peppe. New York: Penguin.

Millay, E. ST. V. 1952. Letters. Ed. A. R. Macdougall. New York: Harper.

Millay, E. St. V. 2002. The Selected Poetry of Edna St. Vincent Millay. Ed. N. Milford. New York: The Modern Library. 